\title{
Pengaruh Bencana Banjir dan Rob Terhadap Ketahanan Ekonomi Kawasan Perdagangan Johar di Kota Semarang
}

\author{
The Impact of Flooding Disaster to Economic Activities in the Old Trading Area \\ in Johar Semarang
}

\author{
Wakhidah Kurniawati1 \\ Universitas Diponegoro, Semarang, Indonesia \\ Djoko Suwandono²
}

\begin{abstract}
Abstrak: Kota Semarang merupakan daerah pantai atau daerah pesisir yang terletak di dataran rendah, dan dialiri beberapa sungai penting, seperti Kali Semarang, Banjir Kanal Barat dan Banjir Kanal Timur, serta sungai-sungai yang lain. Sejak jaman pendudukan Belanda, banjir sudah menjadi fenomena alam dan bencana tahunan di Kota Semarang. Banjir genangan dan banjir pasang air laut, menggenangi bagian utara dan bagian tengah Kota Semarang, termasuk Kawasan Perdagangan Johar Semarang. Kawasan perdagangan Johar Semarang merupakan pusat perdagangan regional yang mendapat ancaman banjir dan rob setiap tahunnya. Ancaman banjir dan rob ini akan sangat mempengaruhi kebertahanan aspek ekonomi kawasan yang ada sebagai pusat komersial dan jasa. Tidak bagusnya infrastruktur kawasan serta penurunan muka tanah juga memberi pengaruh terhadap kontinuitas banjir dan rob ini. Kondisi kawasan yang semakin kumuh, tenggelam, dan mengalami degradasi fisik visual menjadi alasan untuk ditinggalkan. Bangunan konservasi menjadi rusak, dan kawasan semakin kehilangan identitasnya. Untuk itulah, perlu penelitian lebih lanjut untuk mengidentifikasi dan memetakan potensi dan masalah kawasan rawan banjir di Semarang, ditinjau dari aspek fisik dan non fisik. Dari pemetaan potensi dan masalah kawasan rawan banjir dan analisis pendukung lain, diharapkan bisa disusun dari model pengaruh banjir dan rob terhadap kebertahanan aspek ekonomi kawasan.
\end{abstract}

Kata kunci: kawasan rawan banjir; kebertahanan ekonomi

\begin{abstract}
Johar Area as a part of Semarang Heritage Area is currently experiencing physical degradation, social, and economic. This degradation is caused by environmental factors in addition to flood and rob. Degradation resulted in the area into areas of marginal, unproductive, and ultimately become a burden to the city of Semarang. Of course this is very worrying. Because, marginality and flood condition, making the region more and more slums and drowning, damage the buildings and environment, as well as economic resiliency has changed because of the condition. This is the basic need for an understanding of economic resiliency and sustainability of Johar Area in Semarang.
\end{abstract}

Keywords: flooding area; economic resiliency

\footnotetext{
Korespondensi Penulis: Universitas Diponegoro, Semarang, Indonesia Email: wakhidahkurniawati3@gmail.com

2 Korespondensi Penulis: Universitas Diponegoro, Semarang, Indonesia Email: dsuwandono@gmail.com
} 
Pendahuluan
Ketahanan ekonomi suatu kawasan merupakan aspek penting dalam mendukung penataan ruang yang adaptif terhadap kondisi fisik alam, lingkungan, dan juga sosial budaya masyarakat setempat. Sebagai kota yang menjadi langganan banjir tahunan, terutama setiap musim hujan, Semarang, seharusnya memiliki satu model pengaruh ketahanan kawasan yang tanggap terhadap bencana tahunan ini.

Kerugian akibat banjir dan tanah longsor di Kota Semarang mencapai Rp 13,4 miliar. Kerugian terbesar berupa kerusakan infrastruktur jalan dan drainase. Data yang direkapitulasi Dinas Pekerjaan Umum (DPU) Kota Semarang, tercatat 40 ruas jalan utama rusak, dengan perkiraan kerugian mencapai Rp 6,8 miliar. Banjir, juga mengakibatkan kerugian dalam bentuk kerusakan sistem drainase, yang diperkirakan mencapai Rp 3 miliar. Tentu, hal ini perlu ditindaklanjuti supaya tidak terjadi lagi. Penataan ruang yang memperhatikan ruang bagi air, dan adaptif terhadap kondisi fisik alam yang ada, menjadikan dasar bagi penataan ruang kawasan yang berimbang seperti yang diamanatkan dalam UU Penataan Ruang No.26 Tahun 2007, dan juga UU Sumber Daya Air No. 7 Tahun 2004 (http://sensornasional.blogspot.com diakses tanggalı2 Januari 2008).

Kawasan perdagangan Johar Semarang merupakan bagian kota tua Semarang yang saat ini mengalami degradasi fisik, sosial, dan ekonomi. Degradasi ini selain disebabkan oleh faktor lingkungan dengan adanya banjir dan rob. Degradasi mengakibatkan kawasan ini menjadi bukan lagi menjadi pusat perbelanjaan tujuan bagi masayarakat Semarang terutama ketika terjadi banjir dan rob. Tentu ini sangat memprihatinkan. Karena, Kawasan Perdagangan Johar adalah kawasan berskala regional dan pernah jaya di masa lalunya. Untuk itulah penelitian ini dilakukan untuk mendapatkan gambaran pengaruh bencana terhadap pola ketahanan suatu kawasan perdagangan.

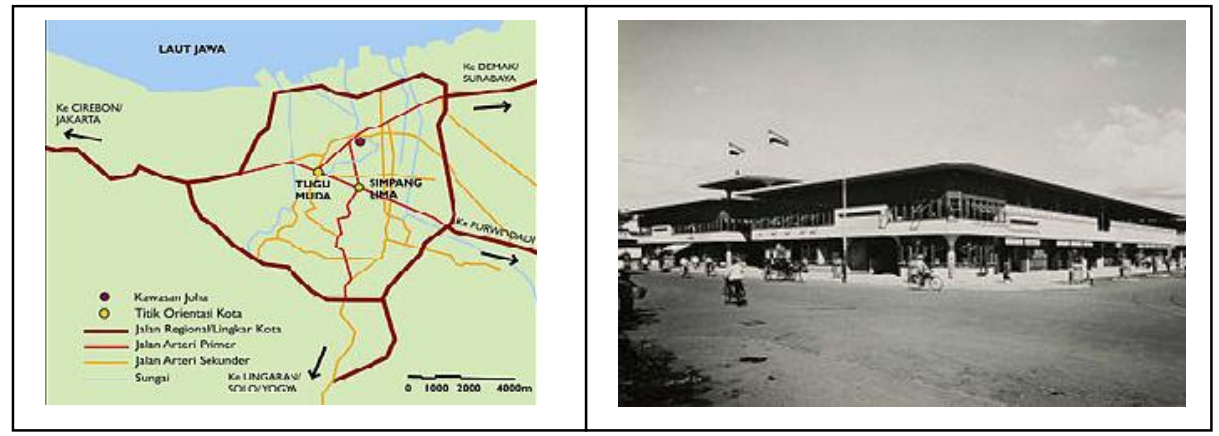

Sumber: Wikipedia diakses Oktober 2012

Gambar 1. Peta Orientasi Kawasan Perdagangan Johar dan Foto Johar 1938-1942

Sejarah Kawasan Perdagangan Pasar Johar Semarang dimulai lebih dari seabad yang lalu. Pada tahun 1860 terdapat pasar yang menempati bagian timur alun-alun ini dipagari oleh deretan pohon Johar ditepi jalan. Dari sinilah nama Pasar Johar itu lahir. Lokasi pasar ini disebelah barat pasar Semarang yang disebut sebagai Pasar Pedamaran, dan berdekatan pula dengan penjara sehingga menjadi tempat menanti orang yang menengok kerabat dan kenalan yang dipenjara. Pasar Johar menjadi semakin ramai dan memerlukan perluasan ruang. Setelah melalui proses pengkajian, akhirnya diadakan perluasan Pasar Johar dengan menebang pohon Johar dan membangun los baru. Pada saat itu pasar ini masih dimiliki oleh pertikelir (swasta). Pada tahun 1931 itu gedung penjara tua yang terletak didekat pasar Johar dibongkar sehubungan dengan rencana pemerintah kota untuk mendirikan Pasar Central modern. Pasar Central lantas memang didirikan dengan tujuan mempersatukan fungsi lima pasar yang telah ada, yaitu Pasar Johar, Pasar Pedamaran, Pasar Beteng, Pasar Jurnatan dan Pasar Pekojan. Perluasan Pasar Central dan pertokoan sekitarnya inilah yang menjadi cikal bakal Kawasan Perdagangan Johar (www.SeputarSemarang.com). 


\section{Kawasan Banjir Kota Semarang}

\section{Pendekatan Penelitian}

\section{Kawasan Banjir Kota Semarang}

Kawasan banjir Kota Semarang, bisa dikelompokkan dalam kawasan dalam kawasan banjir pasang dan banjir genangan. Bisa juga dikelompokkan dalam kawasan pusat pertumbuhan baru dan kawasan lama (bagian kota tua). Titik-titik banjir sendiri selama ini teridentifikasi terutama di dekat DAS, bagian utara dan tengah Kota Semarang yang termasuk site berkontur datar, serta kawasan yang buruk sistem drainasenya.

Kawasan Perdagangan Johar Semarang merupakan bagian dari kawasan langganan banjir tahunan. Kawasan ini secara administratif masuk dalam wilayah Kecamatan Semarang Tengah. Kawasan ini berdekatan letaknya dengan Kali Semarang sendiri, memiliki panjang $6.264 \mathrm{~m}$ (Rusgiyarto, 2006). Permasalahan lain yang merupakan bagian dari kondisi fisik alam kawasan adalah adanya penurunan air tanah menerus di sepanjng kali Semarang. Kendati kecepatan penurunan tanah ini berbeda setiap tahunnya tetapi hal ini tetap harus diwaspadai dan diperhatikan dalam perencanaan kawasan.

\section{Penanganan Banjir Kota Semarang \\ Beberapa cara penanganan banjir di Kota Semarang adalah sebagai berikut: Pengendalian Banjir}

Dalam upaya mengurangi kerugian akibat bencana banjir, aspek pengendalian banjir adalah sangat penting. Secara umum, pengendalian banjir dapat dibagi menjadi 2 (dua) yaitu upaya struktur dan non struktur. Upaya struktur antara lain pembangunan waduk, floodway, perbaikan alur sungai, retardasi (waduk alam). Untuk kasus Kota Semarang, upaya struktur yang sudah dilakukan adalah pembuatan polder di Kota Lama, normalisasi sungai Banjir Kanal, Kali Semarang, dan DAS lain), pembuatan pompa-pompa banjir, peninggian jalan, dan seterusnya. Sampai saat ini, upaya struktur pengendalian banjir belum berjalan optimal, karena penyelesaian banjir bersifat sektoral dan tidak terpadu dengan drainase kota. Sedangkan upaya pengembangan non struktur antara lain Flood Planning Zooning dan Flood Forecasting and Warning System (FFWS) atau sistem prediksi dan peringatan dini banjir yang meliputi kegiatan prediksi (prakiraan) besar dan kapan akan terjadi banjir sekaligus pemberitahuan kepada masyarakat yang kemungkinan akan terjadinya. Kejadian banjir dapat diantisipasi dengan menggunakan sistem peringatan dini banjir.

\section{Koordinasi Stakeholder Terkait}

Dalam Undang Undang No 7 Tahun 2004 tentang Sumber Daya Air disebutkan bahwa pengendalian banjir/daya rusak air menjadi tanggung jawab pemerintah, pemerintah daerah, pengelola SDA dan masyarakat. Sehingga di dalam pelaksanaan tersebut $\mathrm{di}$ atas seluruh komponen ikut berpartisipasi baik dalam koordinasi maupun penyampaian informasi. Saat ini, pemerintah Kota Semarang sedang menyusun masterplan drainase kota, yang sudah disosialisasikan ke masyarakat tetapi belum diimplementasikan.

\section{Kebijakan tata ruang terkait}

Pembatasan terhadap perkembangan lahan terbangun yang dapat mengurangi daerah penampungan sementara (retarding basin) perlu dilakukan agar air pasang tidak langsung masuk ke pemukiman penduduk tetapi ke daerah retensi terlebih dahulu. Pengaturan terhadap ketinggian peil secara menyeluruh, sosialisasi IMB sesuai aturan, serta perlunya rencana tata ruang kota yang berfungsi sebagai kontrol pembangunan, menjadikan dasar perlunya penyusunan rencana induk kota yang berkelanjutan.

Pendekatan penelitian yang dipakai dalam studi ini adalah pendekatan spasial. Pendekatan spasial dilakukan dengan pemetaan potensi dan masalah kawasan rawan banjir, pemetaan aspek fisik dan non fisik kawasan, sehingga dapat menghasilkan titik-titik rawan dan zonasi kawasan rawan banjir. Dari pemetaan tersebut diharapkan didapat pola pengaruh banjir dan rob dan pola ketahanan aspek ekonomi terhadap kedua bencana tersebut. 
Pembahasan

Keterkaitan Bencana Banjir dan Rob Terhadap

Ketahanan Ekonomi Kawasan Perdagangan Johar
Karakteristik Aktivitas Ekonomi di Kawasan Perdagangan Johar

Kawasan perdagangan Pasar Johar memiliki karakteristik aktivitas ekonomi yang beragam karena kawasan tersebut termasuk kawasan pasar berskala regional di Kota Semarang. Aktivitas ekonomi tersebut mencakup aktivitas perdagangan dan jasa. Untuk aktivitas perdagangan terdiri dari Pasar, PKL, Pertokoan, dan warung makan. Sedangkan yang mencakup bidang jasa antara lain Perbankan, Perhotelan, dan Pergudangan.

\section{Tabel 1. Jenis dan Karakteristik Aktivitas Ekonomi di Kawasan Studi}

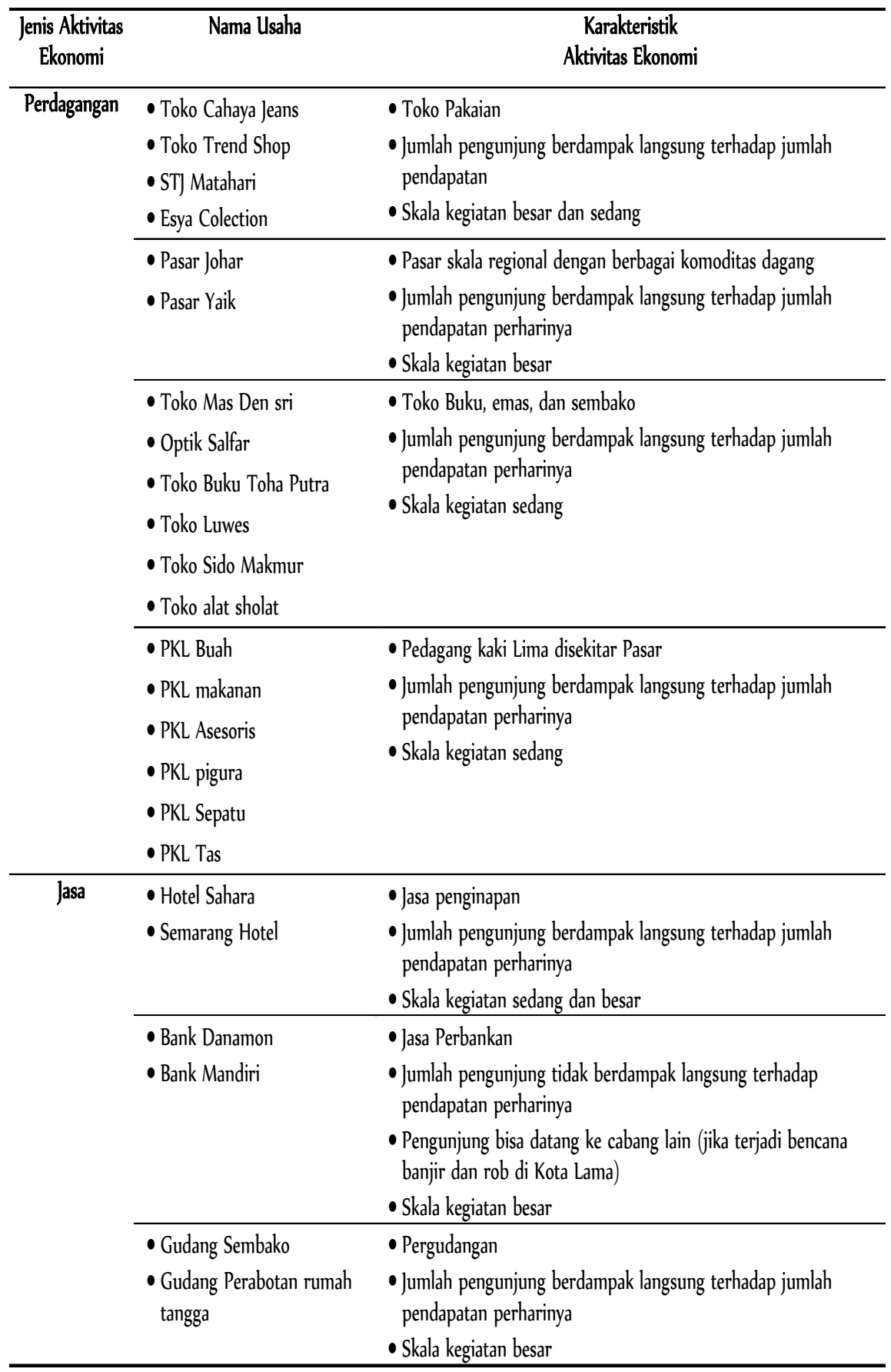

Sumber: Observasi, 2012 


\section{Karakteristik Rawan Bencana Banjir dan Rob di Kawasan Perdagangan Pasar Johar}

\section{A. Analisis Frekuensi Banjir dan Rob di Kawasan Perdagangan Johar}

Bencana rob atau banjir yang berada di kawasan perdagangan Pasar Johar memiliki intesitas yang cukup sering jika pada saat musim penghujan. Jika pada musim kemarau rob atau banjir jarang terjadi ditempat tersebut walaupun kadang juga tejadi rob. Sedangkan jika pada musim penghujan pada kawasan tersebut intensitas terjadnya rob hampir setiap hari dan hal tersebut sangat merugikan bagi pedagang jika dilihat dari segi finansialnya. Dari hasil kuesioner juga dapat dilihat jika banjir atau rob terjadi pada musim penghujan yaitu rata-rata hampir $3 x$ dalam seminggu. Kondisi ini dapat dilihat pada gambar diagram dibawah ini. Terjadinya banjir genangan yang sangat sering ini dikarenakan salah satu penyebab utamanya adalah adanya pendangkalan pada Kali Semarang sehingga mengakibatkan air naik ke permukaan.

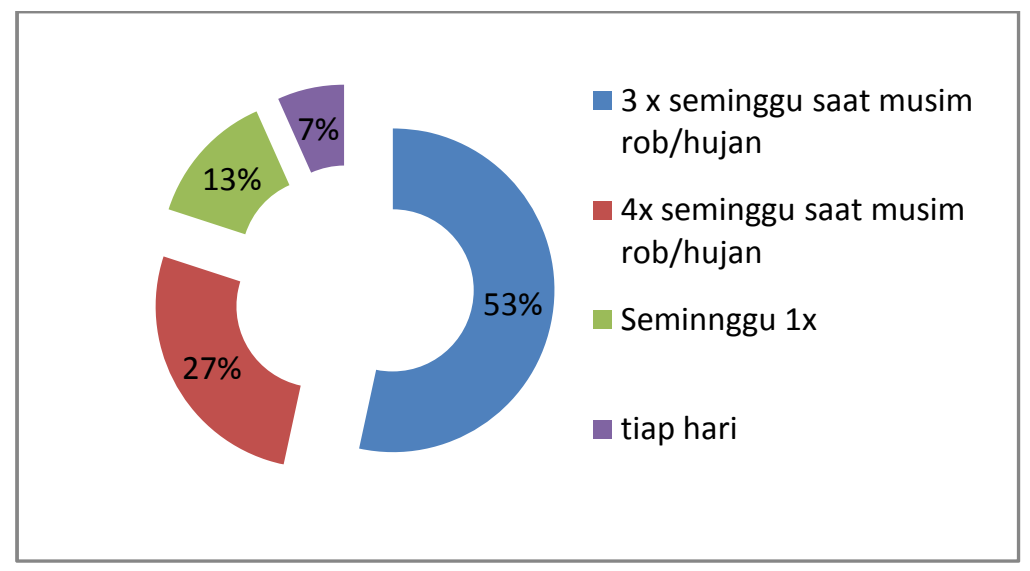

Gambar 2. Frekuensi Terjadi Banjir dan Rob

Pie chart tersebut juga menunjukkan sekitar hampir 100\% aktivitas ekonomi yang ada pada kawasan Perdagangan Pasar Johar mengalami bencana banjir dan rob hanya pada saat musim penghujan dan pada saat hujan lebat, hal ini dikarenakan kondisi drainase kawasan pedagangan Johar banyak tersumbat oleh adanya sampah, kerusakan pompa dan juga posisi bangunan yang ada di Pasar Johar lebih rendah dari Kali Semarang sehingga banjir atau rob pun sangat mungkin dan sering terjadi di kawasan tersebut.

\section{B.Analisis Durasi Genangan Banjir dan Rob di Kawasan Perdagangan Pasar Johar}

Bencana banjir dan rob juga dipengaruhi oleh durasi atau lama genangan yang terjadi di kawasan tersebut, karena dengan semakin lamanya terjadi genangan banjir dan rob maka akan sangat mempengaruhi aktivitas ekonomi yang ada. Pada gambar dibawah diketahui sekitar $40 \%$ aktivitas ekonomi yang berada pada titik kawasan dengan durasi genangan sekitar satu hari. Hal ini sangat merugikan aktivitas ekonomi yang berada kawasan tersebut, begitu juga dengan yang lainnya, yakni sekitar $20 \%$ aktivitas ekonomi yang berada pada titik kawasan dengan durasi genangan selama 12 jam. Kondisi seperti ini terjadi karena lokasi aktivitas ekonomi yang terletak pada daerah yang lebih rendah dari pada daerah sekitarnya dan merupakan titik daerah cekungan sehingga air hujan akan menggenangi daerah tersebut dengan durasi yang lebih lama, selain itu juga diperparah dengan kondisi drainase yang tidak berfungsi optimal sehingga genangan banjir tidak mampu mengalir ke saluran drainase lainnya.

Sekitar 27\% aktivitas ekonomi yang berada pada titik kawasan dengan durasi genangan sekitar satu jam ini merupakan salah satu tempat yang paling sebentar terkena rob karena lokasi tempat usaha yang berada pada titik daerah tersebut cukup tinggi sehingga genangan air akan mengalir ke daerah sekitarnya yang lebih rendah. 


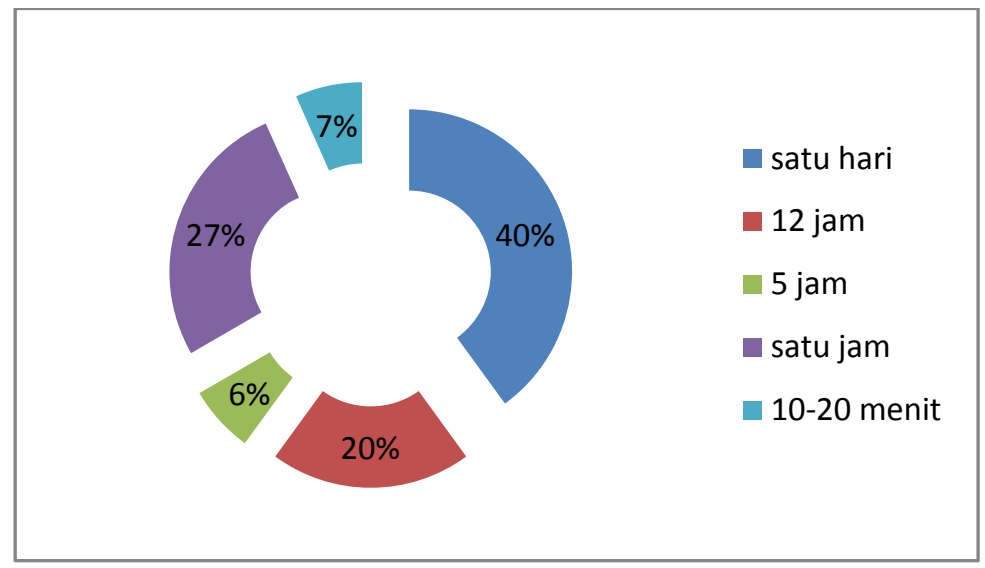

\section{Gambar 3. Durasi Genangan Banjir dan Rob}

\section{Analisis Tinggi Genangan Banjir dan Rob}

Hal lain yang juga sangat mempengaruhi dampak dari bencana banjir dan rob yang terjadi dapat dirasakan dari ketinggian banjir dan rob yang terjadi di Kawasan Perdagangan Johar. Ketinggian banjir dan rob yang terjadipun bervariasi di beberapa titik kawasan yang ada di kawasan tersebut.

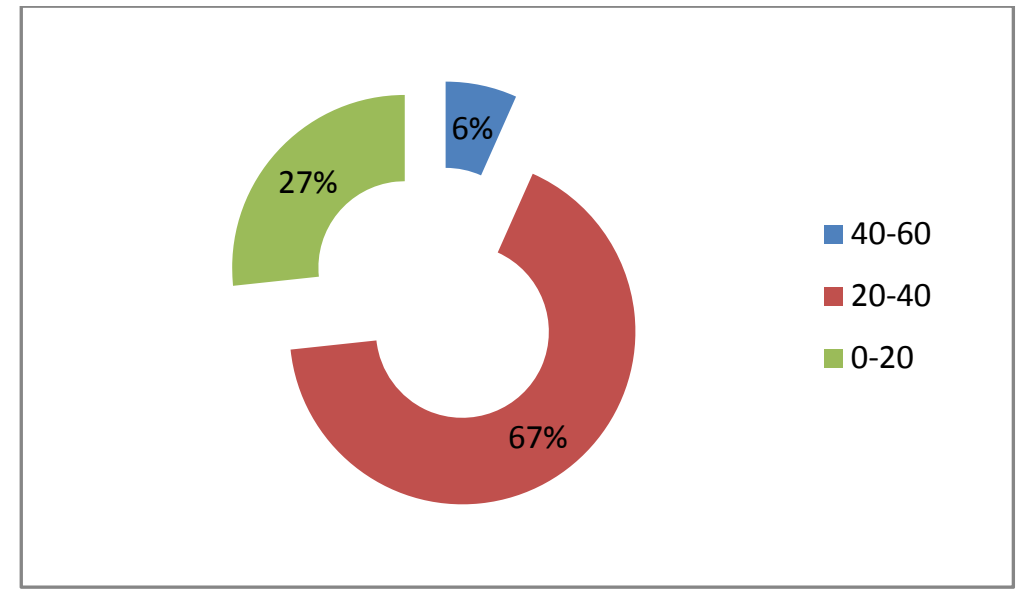

Gambar 4. Tinggi Genangan Banjir dan Rob (cm)

Berdasarkan Gambar diatas diketahui sekitar 67\% Kawasan Perdagangan Johar terjadi genangan banjir dan rob dengan ketinggian $20-40 \mathrm{~cm}$. Kondisi seperti ini terjadi hampir diseluruh kawasan seperti di sebagian Jl. Agus Salim. Dan Jl. Pedamaran 1 yang berada pada elevasi jalan yang tergolong agak rendah. Selain itu terjadi juga genangan banjir dan rob sekitar $27 \%$ dengan ketinggian $0-20 \mathrm{~cm}$ yang terdapat pada Jl. Alun-alun Barat kondisi ini dikarenakan pada jalan tersebut memiliki elevasi cukup tinggi dan juga letaknya agak jauh dari Kali Semarang.

Hanya sekitar 6\% kawasan Kota Perdagangan Johar yang mengalami genangan banjir dan rob dengan ketinggian mencapai 40-60 cm, yaitu: disebagian Jl. Agus Salim yang memang berada pada kondisi jalan dengan elevasi yang tergolong rendah dan merupakan cekungan sehingga menjadi kantung-kantung air pada saat terjadi musim penghujan tiba. Selain itu jalan tersebut cukup dekat dengan Kali Semarang sehingga sering sekali menjadi luberan air dari Kali Semarang yang naik ke permukaan. 
Analisis Aspek Kerentanan Aktivitas Ekonomi Kawasan Perdagangan Johar

Bencana banjir yang terjadi di Kawasan Johar Semarang memberi dampak yang cukup besar bagi kegiatan atau aktivitas yang ada di dalam kawasan tersebut khususnya pada aktivitas perekonomian yang merupakan sektor cukup mendorong perkembangan Kawasan Perdagangan Johar. Dapat dilihat bentuk kerentanan yang diakibatkan sangat berpengaruh terhadap kinerja sebuah usaha yang dilakukan antara lain yaitu, terjadinya fluktuasi atau perubahan terhadap jumlah pendapatan, jumlah pengunjung, frekuensi kegiatan (jam kerja), jumlah tenaga kerja.

\section{Jumlah Pendapatan}

Dampak banjir dan rob yang terjadi memang menimbulkan kerentanan pada tiap-tiap aktivitas ekonomi yang ada di Kawasan Johar Semarang. Adapun bentuk kerentanan yang terjadi antara lain perubahan terhadap jumlah pendapatan yang dirasakan oleh para pelaku usaha di kawasan tersebut.

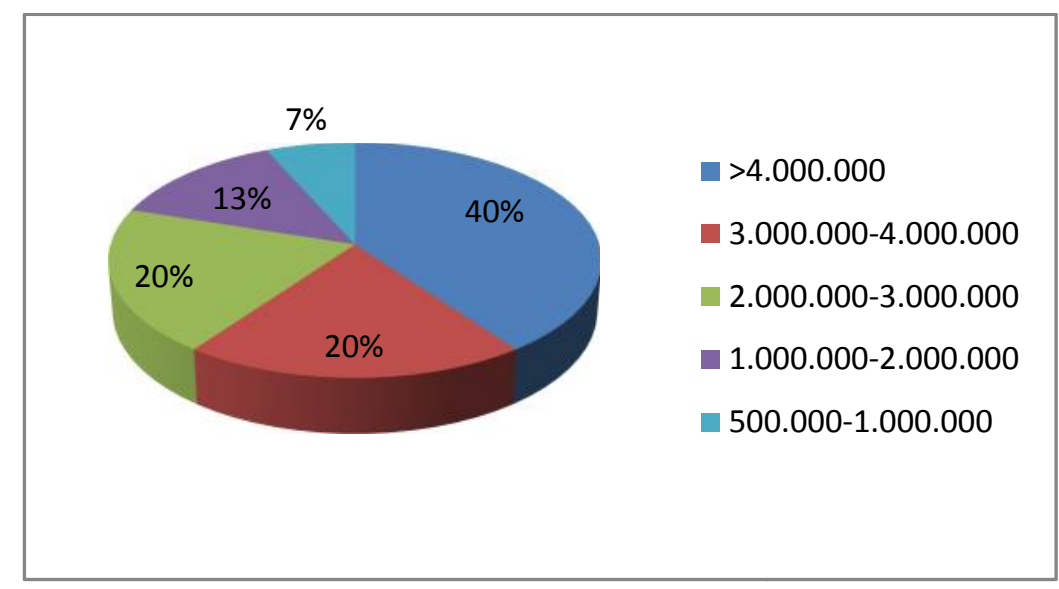

Gambar 6. Jumlah Pendapatan Saat Tidak Terjadi Banjir dan Rob

Pada gambar diatas terlihat tingkat pendapatan yang diperoleh saat tidak terjadi bencana banjir dan rob. Diketahui bahwa jumlah pendapatan dengan kisaran $>$ Rp.4.000.000/hari mencapai 40\%, dan sekitar 20\% aktivitas ekonomi yang ada memiliki jumlah pendapatan Rp.3000.000-4000.000/bulan serta 20\% dari aktivitas ekonomi yang ada memiliki pendapatan rata-rata sebesar Rp.2000.000Rp.3000.000/bulan dan seterusnya. Hal ini menunjukkan bahwa hampir dari setengah jumlah aktivitas ekonomi yang ada memiliki jumlah pendapatan yang cukup besar terutama pada bidang jasa yang melayani baik dalam maupun di luar Kawasan Johar. Selain itu, diketahui juga bahwa dengan melihat tingkat pendapatan yang diperoleh oleh masing-masing aktivitas ekonomi yang ada, secara tidak langsung mampu menjadi penggerak bagi perekonomian di Kawasan Perdagangan Johar Semarang karena memberikan pemasukan yang cukup menguntungkan pada saat tidak terjadi bencana banjir dan rob.

Berbeda halnya dengan kondisi jika terjadi bencana banjir dan rob pada saat musim penghujan. Terjadi fluktuasi atau perubahan terhadap jumlah pendapatan yang signifikan pada sebagian aktivitas ekonomi yang ada, yang dapat dilihat pada gambar berikut. 


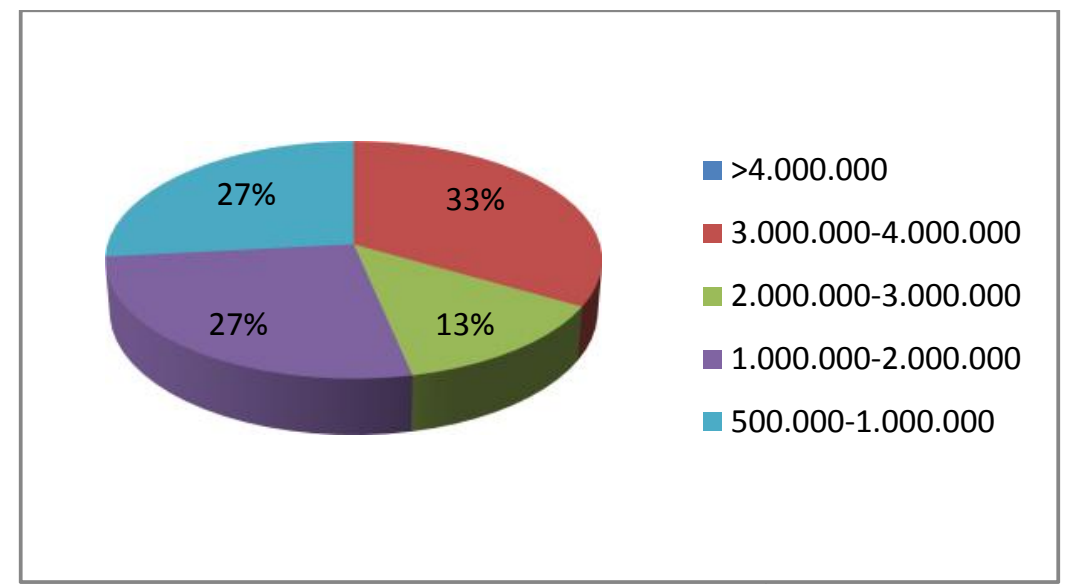

Gambar 7. Jumlah Pendapatan Saat Musim Banjir dan Rob

Pada gambar dan tabel diatas diketahui bahwa terjadi perubahan terhadap jumlah pendapatan yang diperoleh oleh para pelaku usaha. Jumlah pendapatan yang berkisar lebih dari Rp.4.000.000/bulan turun menjadi 33\% dan sekitar 13\% pada rata-rata pendapatan sejumlah Rp.3000.000-Rp.4.000.000/bulan dan seterusnya seperti yang terlihat pada grafik dibawah ini.

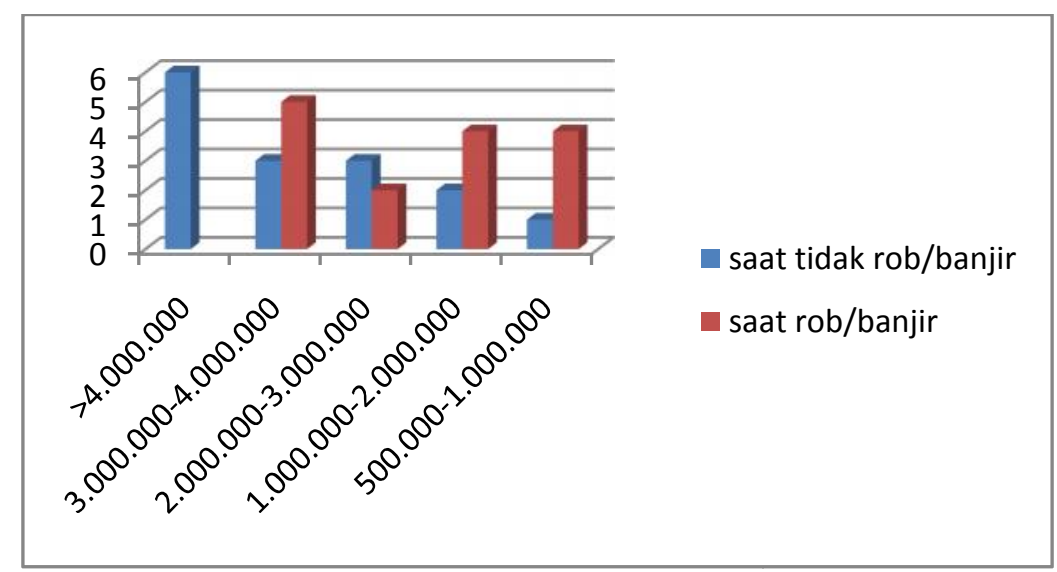

Gambar 8. Grafik Perubahan Pendapatan Saat Musim Banjir dan Rob

Pola Ketahanan Aktivitas Ekonomi Terhadap Dampak Bencana Banjir dan Rob
Bencana banjir dan rob memang kerap terjadi di Kawasan Perdagangan Johar, hal ini disebabkan selain kondisi fisik alam yang tidak mendukung juga kondisi prasarana yang tidak memadai sehingga tidak mampu mengatasi masalah banjir dan rob yang terjadi di kawasan tersebut. Berdasarkan hasil kuesioner dan pengamatan dilapangan diperoleh data terkait respon masyarakat terhadap bencana banjir dan rob yang terjadi serta upaya adaptasi ada yang telah dilakukan oleh masing-masing aktivitas ekonomi yang ada pada daerah rawan bencana tersebut untuk mengatasi kerentanan yang berdampak tidak langsung terhadap aktivitas ekonomi di Kawasan Perdagangan Johar.

Aktivitas ekonomi yang berada di Kawasan Perdagangan Johar Semarang masih eksis hingga saat ini, dan rata-rata sudah berdiri hingga puluhan tahun lamanya. Hal ini menandakan bahwa tempat usaha yang disana sudah mengalami begitu banyak kejadian seperti halnya bencana banjir dan rob yang terjadi di Perdagangan Johar Semarang.

Berdasarkan hasil pengamatan di lapangan diketahui bahwa aktivitas ekonomi yang ada di kawasan tersebut walau sudah terbiasa dengan kejadian alam yang melanda tempat usaha mereka akan tetapi kondisi ini sangat mempengaruhi aktivitas ekonomi didalamnya. 
Tabel 2. Pengaruh Rob dan Banjir Terhadap Aktivitas Perdagangan

\begin{tabular}{|c|l|l|}
\hline No & Nama Perusahaan & Pengaruh \\
\hline 1 & PKL Asesoris & Berpengaruh \\
\hline 2. & PKL Buah & Berpengaruh \\
\hline 3. & PKL perabotan & Tidak berpengaruh \\
\hline 4. & PKL Asesoris & Berpengaruh \\
\hline 5. & PKL Kaus Kaki & Tidak berpengaruh \\
\hline 6. & PKL Makanan & Berpengaruh \\
\hline 7. & PKL Buah & Berepengaruh \\
\hline 8. & PKL Pigura \& kaligrafi & Berpengaruh \\
\hline 9. & PKL Sembako & Berpengaruh \\
\hline 10 & PKL Makanan & Berpengaruh \\
\hline 11. & Toko Cahaya Jeans & Berpengaruh \\
\hline 12 & Toko Makmur & Berpengaruh \\
\hline 13 & Toko Optik Salfar & Berpengaruh \\
\hline 14 & Toko Plastik & Berpengaruh \\
\hline 15 & Toko Perlengkapan Sholat & Berpengaruh \\
\hline
\end{tabular}

Sumber: Analisis, 2012

Kesimpulan

\section{Ucapan Terimakasih}

Daftar Pustaka
Berdasarkan tujuan penelitian ini yaitu merumuskan pola ketahanan aktivitas ekonomi pada daerah rawan bencana rob dan banjir tahunan di Kawasan Perdagangan Johar yaitu sebagai berikut:

Mayoritas aktivitas perdagangan yang ada di Kawasan Perdagangan Johar mengalami kerentanan. Terlihat dari perubahan jumlah pendapatan yang terjadi perubahan jumlah pengunjung, yang dimana aktivitas tersebut sangat dipengaruhi oleh banyaknya pengunjung yang datang sehingga sangat berdampak terhadap pendapatan yang diterima. Selain itu juga terjadi perubahan terhadap jumlah tenaga kerja maupun jumlah jam kerja pada saat terjadi bencana rob dan banjir tahunan.

Kawasan inti yang bertahan terhadap banjir dan rob di Kawasan Perdagangan Johar adalah kawasan sekitar Masjid Kauman karena intensitas rob rendah, kawasan transisi adalah kawasan Pasar Johar dan Pedamaran karena intensitas rob sedang; sedangkan kawasan yang paling rentan adalah kawasan sepanjang Jalan Agus Salim karena intensitas rob tinggi.

Terimakasih atas pembiayaan dengan sumber dana PNBP UNDIP Tahun Anggaran 2012, melalui DIPA Nomor: 0596/023-04.2.16/13/2012 tanggal 16 Februari 2012 yang telah membantu dalam pelaksanaan penelitian dan penulisan artikel.

Dwi-60. Semarang-Demak Ambles $8 \mathrm{Cm}$ Per Tahun, Semarang, Suara Merdeka, Jumat, 23 Nopember 2007.

Kurniawati, Wakhidah. The Old Multiethnic Kampong Along Semarang River as Romantic Image in Semarang. City Marketing and Heritage International Conference. Semarang, Indonesia. 2007.

Kurniawati, Wakhidah. The Old Multiethnic Kampong Along Semarang River. Waterfront Development International Seminar. Jakarta, Indonesia. 2nd August 2006.

Kurniawati, Wakhidah. "Penataan Kawasan Lama sebagai Kawasan Wisata Budaya. Studi Kasus: Kampung Lama Sepanjang Kali Semarang". Thesis tidak diterbitkan. Bandung: ITB. 2002.

Kodoatie, Robert J. Tata Ruang dan Sumber Daya Air. Seminar Internasional "Interaksi Tata Ruang dan Air". Universitas Diponegoro, Semarang. 15 Mei 2008.

Kodoatie, Robert ] dan Sugiyanto. Banjir, Beberapa Penyebab dan Metode Pengendaliannya dalam Perspektif Lingkungan. Semarang, Pustaka Pelajar. 2001

Rosalina, Puteri. "Pengaruh Pertambahan Jumlah Penduduk dan Perluasan Area Terbangun terhadap Banjir (Studi Kasus: DAS Beringin dan Plumbon Kota Semarang)". Tugas Akhir tidak diterbitkan. Semarang: Universitas Diponegoro. 2000.

Rusgiyarto, Anwar. "Strategi Peningkatan Kualitas Lingkungan Permukiman di Tepi Kali Semarang". Tugas Akhir tidak diterbitkan. Semarang: Universitas Diponegoro. 2005.

Setiyanto, Heru. "Studi Pengaruh Penurunan Muka Tanah dan Pasang Surut Air Laut terhadap Banjir dan Rob di Kecamatan Semarang Utara". Tugas Akhir tidak diterbitkan. Semarang: Universitas Diponegoro. 2002. 
Yuni Ikawati. Penurunan Tanah. Bencana Ambles Mengintai di Pantai. Kompas. Jumat, 2 Mei 2008 00:38 WIB

Undang-Undang Republik Indonesia Nomor 7 Tahun 2004 Tentang Sumber Daya Air

Undang-Undang Republik Indonesia No.26 Tahun 2007 Tentang Penataan Ruang

http://sensornasional.blogspot.com/2008/01/kerugian-banjir-dan-longsor-rp-134-m. 12 Januari 2008

www.walhi.co.id. Sofyan. Mendapatkan Perlindungan dan Keselamatan dari Ancaman Banjir adalah Hak Asasi Rakyat. 